\title{
Healthcare seeking preferences of Myanmar migrant seafarers in the deep south of Thailand
}

\author{
Pyae Phyo Kyaw ${ }^{1,}{ }^{\oplus}$, Alan F. Geater ${ }^{1}(\mathbb{0}$ \\ ${ }^{1}$ Epidemiology Unit, Faculty of Medicine, Prince of Songkla University, Hatyai, Songkhla, Thailand \\ ${ }^{2}$ Directorate of Medical Services, Nay Pyi Taw, Myanmar
}

\begin{abstract}
Background: The Thai marine fishing industry depends on migrant workers. Public healthcare services are officially available to all registered migrant workers, but the extent of their utilisation by migrant seafarers is unknown. The aim of the study was to document sociodemographic characteristics, working conditions, illness history and healthcare-seeking preference among Myanmar migrant seafarers in southern Thailand. Materials and methods: Questionnaire-based interviews were conducted among 385 migrant seafarers and selected participants qualitatively interviewed. Factors related to illness experience and to healthcare-seeking preference were identified using logistic regression.

Results: Past-one-year illness was reported by 307 (80\%) participants, among whom 91\% had illness while at sea and $22 \%$ an emergency condition requiring immediate transfer ashore. Only $118(38 \%)$ illness events involved visiting a public hospital; another $38 \%$ involved private healthcare facilities or drug stores. Illness was associated with supervisory job, alcohol consumption habit, age $>20$ years, ethnicity and exposure to hazardous marine life. Compared with the choice of public hospital, use of private healthcare facilities was associated with having at least primary school education and shorter-duration trips at sea. Obtaining medications from a drug store was associated with the job of sorting, packing/storing the catch, non-drinking and low income. Not holding their identity and health-insurance documents and language barrier were major reasons for reluctance to seek treatment at a public hospital.

Conclusions: Illness was common among the migrant seafarers. Utilisation of public hospitals was low. Allowing migrants to keep their identity and health insurance documents themselves and providing materials in the Myanmar language might promote utilisation of public health facilities.
\end{abstract}

(Int Marit Health 2021; 72, 1: 1-9)

Key words: Myanmar migrant seafarers, illness, healthcare-seeking preferences

\section{INTRODUCTION}

The international migrant population has been increasing globally over the past few decades. According to World Migration Report launched by International Organization for Migration, in 2015, 3.3\% of the world's population migrates around the world and work was the major reason for migration [1]. According to Thailand migration report, in 2018 , there were about 4.9 millions of migrant workers working in different sectors [2]. Migrant workers who come to Thailand typically work in industries such as fisheries, agriculture, manufacturing, construction and the service industries, the majority of them are working in physically demanding manual labour or low or semi-skilled jobs [3].

The Gulf of Thailand and the Andaman coastal area are the main marine fishing hubs occupying all the coastal provinces, where 600,000 migrant workers are working in fishing and seafood processing industries [2]. As of 2016 statistics from the Labour Office, in Pattani province alone, which is

Dr. Pyae Phyo Kyaw, Epidemiology Unit, Faculty of Medicine, Prince of Songkla University, Hatyai, Songkhla, Thailand, e-mail: drpyae@gmail.com 
one of the deep southern provinces of Thailand, registered 12,000 migrant workers were working, mainly in fisheries [4]. Fishing communities are socially, economically and educationally disadvantaged and characterized by overcrowding and congestion with extremely poor sanitation [5]. Fishing itself is a particular type of hazardous and stressful job as it presents prolonged hours of continuous monotonous fishing trips, adverse weather, and stressful working condition at sea [6]. Long working days, heat in the work place, separation from families and hectic working activities are important stressors for seafarers [7]. Apart from risk of fatal injuries and accidents, lifestyle of seafarers involving irregular diet, drugs and alcohol misuse and risky sexual behaviours has a negative influence on their health [6].

Health needs and limitations of accessibility to health care services are frequently encountered among migrants [8]. Health insurance coverage has an influence on health-seeking behaviour of migrants in China [9]. In Thailand, migrants who have work permits are fully covered by Thai social security scheme, which mandates equal rights of access to health services with Thai nationals [10]. Although all documented and non-documented migrants can purchase migrant health insurance, utilisation of health service among insurance members is still low [3]. Moreover, though the uninsured migrants have formal access to healthcare services, they have to pay all expenses on their own as they do not have insurance [11]. Apart from major health problems, migrants tended to seek health care at private clinics or took medicine pills from drug store as service providers did not request identification cards or information on their background [12].

A study in Ranong province highlighted the nature of seafarers' healthcare preference that they were at sea for a long time and likely to ignore their health problems [12]. It has been reported that seafarers have been involved in medical emergencies at sea which required them being taken ashore, thus emphasizing the very dangerous nature of their job [13]. Unlike other migrants, migrant-seafarers have different working experiences and they are in a high-risk occupation. However, little health research on migrant workers in Thailand's fishing and seafood industry has been conducted.

Therefore, the objective of this study was to explore the socio-demographic profile of Myanmar migrant seafarers in Pattani province, Thailand, to document their healthcare-seeking preferences and to identify the factors responsible for their decision of those preferences. Seafarers' working condition at sea, living condition offshore, their health-related experiences and their preferences for seeking health treatments were considered in this study. The findings in this study are expected to partially fill the research gaps in migrant seafarers' health issues and could provide evaluation feedback to healthcare policy makers.

\section{MATERIALS AND METHODS STUDY SETTINGS AND DESIGN}

A community-based study was conducted during November, 2016 to April, 2017 in Pattani, one of the deep south provinces of Thailand bordering Malaysia. With the help of key informants, the seafarer community in Meuang district was approached and observed to obtain information at major sites of migrant residence and at fishing piers. Details of types of fishing boats, job types, ethnic groups and life styles were noted. A cross-sectional survey was then conducted using a questionnaire which was developed based on initial observation data. Inclusion criteria for recruitment were: being an adult male Myanmar migrant seafarer, having resided in Mueang district of Pattani province for at least one year, and having experience of going to sea. A subset of these migrants was subsequently interviewed qualitatively to clarify the findings of the quantitative questionnaire.

\section{SAMPLE SIZE AND SAMPLING METHODS}

We assumed a prevalence of various health characteristics, needs, nature of accessibility to health care services, health perception and health-related experiences of $50 \%$ (no previous data) with a margin of error of $\pm 5 \%$, for which a sample of 385 was required. Based on information from the Pattani Labour Office, it was estimated that there would be around 7000 male Myanmar migrant seafarers based in Pattani, so the sampling fraction would be around $5 \%$.

When not at sea, most seafarers lived in camps but some stayed on the boat even while docked at the fishing piers. Sampling was done in the seafarers' housing as well as at fishing piers by snowball methodology. Successive places were introduced by key informants from each housing camp to another. Within each camp, all the rooms in the camp were numbered, and selected for interview using a random number table. We interviewed a random-number-generated respondent from each selected room to fulfil the expected sample size in accordance with the inclusion and exclusion criteria. If a selected participant had difficulty in speaking Myanmar language, an interpreter was engaged. No restriction on ethnicity was applied but the respondent had to originate from Myanmar.

Of the seafarers, 385 respondents were chosen in accordance with the inclusion and exclusion criteria. Written informed consent was obtained after providing thorough explanation to each potential subject. For the qualitative component, participants were selected based on their type of job and rank, and their willingness to participate in the interview and reveal their living experience and their working experience. Six crew supervisors and fifteen crew members were participated in in-depth interviews. 


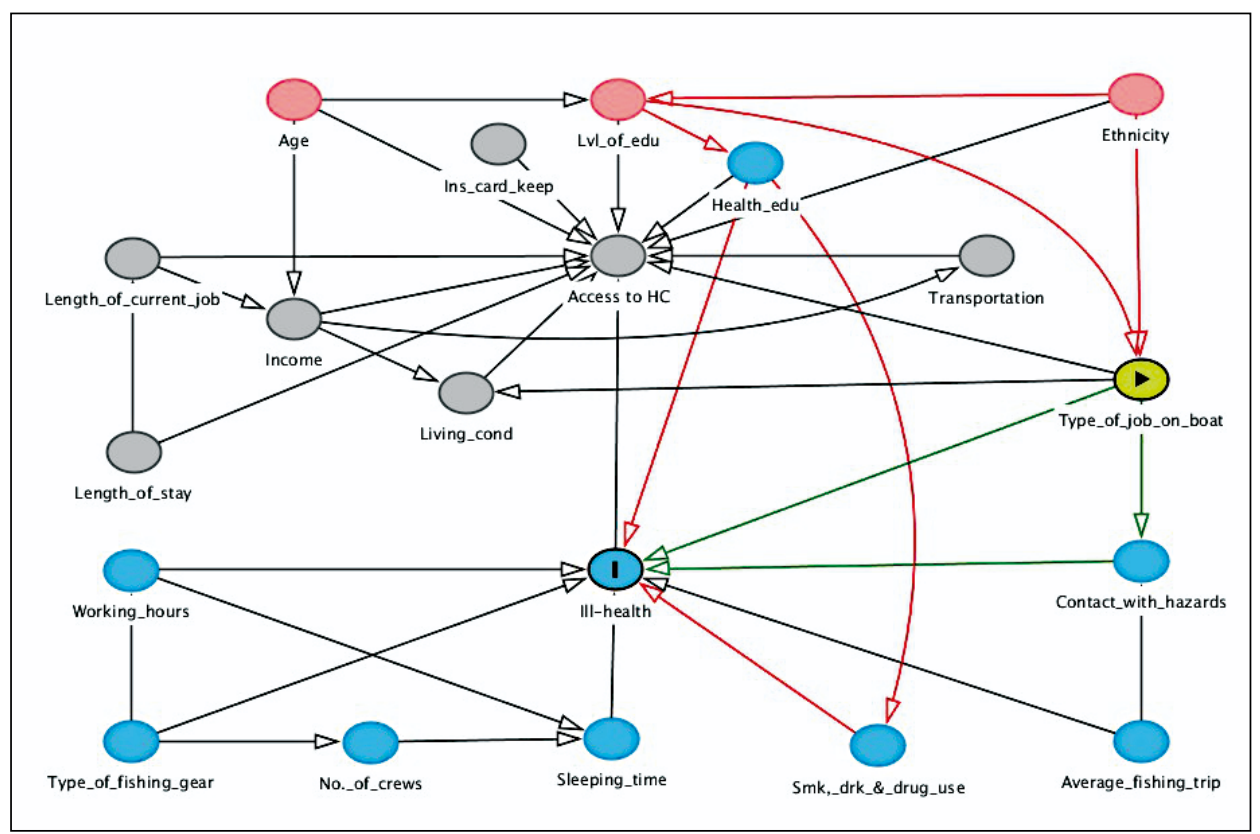

Figure 1. Directed acyclic graph showing the hypothesized relationships of sociodemographic characteristics, work conditions and other health-related exposures with occurrence of ill health and healthcare-seeking preferences among migrant Myanmar seafarers in Meuang Pattani, Thailand

\section{ETHICAL CONSIDERATION}

The study was approved by the Ethics Committee of the Faculty of Medicine (Document number 59-322-18-5) and performed in line with the principles of the Declaration of Helsinki. Participants' anonymity and confidentiality was stringently maintained throughout the study.

\section{DATA MANAGEMENT AND STATISTICAL ANALYSIS}

The data obtained using the structured questionnaire were checked for completeness, accuracy and consistency and double entered using Epidata version 3.1. All analysis was performed using $\mathrm{R}$ version 3.2.5. Descriptive summaries of socio-demographic characteristics, working conditions, accessibility to healthcare services and health related characteristics were made using tabulation. A directed acyclic graph (DAG) was constructed to represent the possible pathways influencing the risk of illness of seafarers and for the choice of healthcare centre to access healthcare (Fig. 1). Associations between the independent variables (illness in the previous year, choice of healthcare facility) and dependent variables were done by univariate analysis. Binary logistic regression controlling for confounding as indicated by the DAG, was used to identify factors related to experience of illness in the previous year.

Multinomial logistic regression models, similarly controlled for minimal required sets of adjustment variables as indicated by the DAG, were constructed to identify factors influencing choice of type of healthcare facility among those who had experienced illness within the previous year.
Considering the baseline category of health facility to be public hospital, a relative risk ratio greater than 1 for the choice of private facility, drug store or no healthcare visit indicates higher relative probability of choosing the relevant health facility given the corresponding level of predictor compared with the reference. A likelihood ratio test $p$-value of $<0.05$ was used as the level of significance for each variable, and for the multinomial models the significance of each outcome comparison was indicated using the Wald test.

\section{RESULTS \\ GENERAL CHARACTERISTICS AND WORKING CONDITIONS OF MYANMAR MIGRANT SEAFARERS IN PATTANI DISTRICT, THAILAND}

All 385 seafarers who were approached agreed to participate. Ages ranged from 17 to 53 years and $88 \%$ were more than 20 years old. The major ethnic groups were Rakhine (68\%), followed by Bamar (20\%), Dawei and various other ethnicities (12\%) and 31\% had less than primary education. $30 \%$ of migrant seafarers lived in Thailand for more than 5 years and majority of seafarers (75\%) had been working in current job for less than 5 years. A majority of the respondents (75\%) were current or ex-drinkers.

Although almost all had received regular screening at hospital, only one fourth (27\%) had ever attended a health education session. Almost all respondents had health insurance provided by their employer but only $2.3 \%$ kept the card themselves or with a friend, relative, and with the head of the work group, whereas for the vast majority of seafarers 
Table 1. General characteristics and working conditions of Myanmar migrant seafarers in Pattani district, Thailand

\begin{tabular}{|c|c|c|c|}
\hline Variables & & Frequency & Percentage \\
\hline Age group & $\begin{array}{l}\leq 20 \\
>20\end{array}$ & $\begin{array}{l}47 \\
338\end{array}$ & $\begin{array}{l}12.2 \% \\
87.8 \%\end{array}$ \\
\hline Ethnicity & $\begin{array}{l}\text { Bamar } \\
\text { Rakine } \\
\text { Dawei and others }\end{array}$ & $\begin{array}{l}78 \\
261 \\
46\end{array}$ & $\begin{array}{l}20.3 \% \\
67.8 \% \\
11.9 \%\end{array}$ \\
\hline Education level & $\begin{array}{l}\text { Less than primary } \\
\text { Primary } \\
\text { Middle and above }\end{array}$ & $\begin{array}{l}121 \\
188 \\
76\end{array}$ & $\begin{array}{l}31.4 \% \\
48.8 \% \\
19.7 \%\end{array}$ \\
\hline Length of stay in Thailand (years) & $\begin{array}{l}<5 \\
\geq 5\end{array}$ & $\begin{array}{l}269 \\
116\end{array}$ & $\begin{array}{l}69.9 \% \\
30.1 \%\end{array}$ \\
\hline Working duration in current job (years) & $\begin{array}{l}<5 \\
\geq 5\end{array}$ & $\begin{array}{l}288 \\
97\end{array}$ & $\begin{array}{l}74.8 \% \\
25.2 \%\end{array}$ \\
\hline Drinking history & $\begin{array}{l}\text { Never } \\
\text { Ex and current }\end{array}$ & $\begin{array}{l}98 \\
287\end{array}$ & $\begin{array}{l}25.5 \% \\
74.5 \%\end{array}$ \\
\hline Monthly income & $\begin{array}{l}5000-8000 \text { THB } \\
>8000 \text { THB }\end{array}$ & $\begin{array}{l}166 \\
219\end{array}$ & $\begin{array}{l}43.1 \% \\
56.9 \%\end{array}$ \\
\hline Health insurance card kept in & $\begin{array}{l}\text { Boss/work leader } \\
\text { Self/friend/relative }\end{array}$ & $\begin{array}{l}376 \\
9\end{array}$ & $\begin{array}{l}97.7 \% \\
2.3 \%\end{array}$ \\
\hline Health education experience & $\begin{array}{l}\text { Yes } \\
\text { No }\end{array}$ & $\begin{array}{l}104 \\
281\end{array}$ & $\begin{array}{l}27.0 \% \\
73.0 \%\end{array}$ \\
\hline Type of job on boat & $\begin{array}{l}\text { Supervise crew } \\
\text { Steer vessel/navigation } \\
\text { Mechanic/cook } \\
\text { Sort/pack/store catch } \\
\text { Guide nets/traps/line }\end{array}$ & $\begin{array}{l}33 \\
58 \\
15 \\
258 \\
21\end{array}$ & $\begin{array}{l}8.6 \% \\
15.1 \% \\
3.9 \% \\
67.0 \% \\
5.5 \%\end{array}$ \\
\hline Average duration of job trip & $\begin{array}{l}\leq 10 \text { days } \\
11-15 \text { days } \\
>15 \text { days }\end{array}$ & $\begin{array}{l}188 \\
92 \\
105\end{array}$ & $\begin{array}{l}48.8 \% \\
23.9 \% \\
27.3 \%\end{array}$ \\
\hline Exposure to hazardous marine life & $\begin{array}{l}\text { Yes } \\
\text { No }\end{array}$ & $\begin{array}{l}119 \\
266\end{array}$ & $\begin{array}{l}30.9 \% \\
69.1 \%\end{array}$ \\
\hline
\end{tabular}

THB - Thai Baht

the card was kept by their boss. In respect of type of job on boat, two thirds (67\%) of the respondents were general marine workers whose job was to sort, pack and store the catch, followed by those steering the vessel and navigating (15\%) (Table 1).

\section{HEALTH CONDITION, CHOICE OF HEALTHCARE FACILITY AND HEALTHCARE FACILITY VISIT EXPERIENCE (EXCLUDING DRUG STORE AND NO TREATMENT) OF MYANMAR MIGRANT SEAFARERS IN PATTANI DISTRICT, THAILAND}

Among the 385 respondents, 307 (80\%) reported having been ill in the previous year. Of these $91 \%$ had been ill at sea, 79\% while ashore, 70\% experiencing illness both at sea and ashore. Among the 307 respondents who had experienced illness in the previous year, 118 (38\%) had chosen to visit a public hospital, $17 \%$ a private healthcare facility and $21 \%$ self-medicated with medication purchased from a drug store. The others did not seek treatment. Among respondents seeking treatment at a healthcare facility, half reported the health facility was within $2 \mathrm{~km}$ of their lodging and $87 \%$ reported taking less than 30 min to arrive at the facility. Only about two-fifth reported having to wait more than $30 \mathrm{~min}$ to be attended to by a health-service provider and the majority (87\%) reported being satisfied or very satisfied with the waiting time (Table 2).

\section{ILLNESS (IN THE PREVIOUS YEAR) OF MYANMAR MIGRANT SEAFARERS IN PATTANI DISTRICT, THAILAND $(\mathrm{N}=385)$}

Binary logistic regression models to identify variables significantly associated with seafarers reported illness in the previous year after appropriately controlling for confounding as indicated by the DAG revealed that such illness was significantly associated with holding a supervisory job on the boat, (odds ratio [OR] 7.67; 95\% confidence interval [CI] 
Table 2. Health condition, choice of healthcare facility, and healthcare facility visit experience (excluding drug store and no treatment) of Myanmar migrant seafarers in Pattani district, Thailand

\begin{tabular}{|c|c|c|c|}
\hline Variables & & Frequency & Percentage \\
\hline \multirow[t]{2}{*}{ IIIness history in the previous year } & Yes & 307 & 79.7 \\
\hline & No & 78 & 20.3 \\
\hline \multirow[t]{3}{*}{ Illness location } & At sea and ashore & 214 & 69.7 \\
\hline & Only at sea & 66 & 21.5 \\
\hline & Only ashore & 27 & 8.8 \\
\hline \multirow[t]{4}{*}{ Choice of healthcare facility } & Public hospital & 118 & 38.4 \\
\hline & Private facility & 52 & 16.9 \\
\hline & Drug store & 66 & 21.5 \\
\hline & No treatment & 71 & 23.1 \\
\hline \multicolumn{4}{|l|}{ Healthcare facility visit experience } \\
\hline \multirow[t]{3}{*}{ Distance to healthcare facility $[\mathrm{km}]$} & $<2$ & 88 & 51.8 \\
\hline & $\geq 2$ & 71 & 41.7 \\
\hline & Missing & 11 & 6.5 \\
\hline \multirow[t]{3}{*}{ Time to healthcare facility [min] } & $<30$ & 148 & 87.1 \\
\hline & $\geq 30$ & 11 & 6.5 \\
\hline & Missing & 11 & 6.5 \\
\hline \multirow[t]{3}{*}{ Difficulty to go to healthcare facility } & Difficult & 9 & 5.3 \\
\hline & Easy or very easy & 153 & 90.0 \\
\hline & Missing & 8 & 4.7 \\
\hline \multirow[t]{3}{*}{ Waiting time at healthcare facility [min] } & $<30$ & 92 & 54.0 \\
\hline & $\geq 30$ & 66 & 38.8 \\
\hline & Missing & 12 & 7.1 \\
\hline \multirow[t]{4}{*}{ Satisfied with waiting time at healthcare facility } & Strongly satisfied & 5 & 2.9 \\
\hline & Satisfied & 144 & 84.7 \\
\hline & Dissatisfied and strongly dissatisfied & 9 & 5.3 \\
\hline & Missing & 12 & 7.1 \\
\hline
\end{tabular}

1.01-57.9 compared to the job of sorting, packing and storing the catch), age > 20 years (OR 2.05; 95\% Cl 1.05-4.01), being a current or past alcohol drinker (OR $3.17 ; 95 \% \mathrm{Cl}$ 1.84-5.46), being of Dawei or other minority ethnicity compared with Rakhine (OR 4.46; 95\% Cl 1.34-14.9), and exposure to hazardous marine animals or plants (OR 2.36; 95\% Cl 1.24-4.48) (Table 3). There appeared also to be a positive association between longer residence in the country and longer duration in the current job and probability of experiencing illness in the previous year.

\section{CHOICE OF HEALTHCARE FACILITY AMONG MYANMAR MIGRANT SEAFARERS WHO SOUGHT HEALTHCARE FOR ILLNESS WITHIN THE PREVIOUS YEAR IN PATTANI DISTRICT, THAILAND ( $\mathrm{N}=\mathbf{2 3 6}$ )}

A series of multivariate logistic regression model was constructed for choice of healthcare, comparing private care and drugstore to use of public health care facility, similarly controlling for potential confounding factors as indicated by the DAG. Using public health facility as the baseline outcome, there was evidence that private healthcare facilities were relatively more likely to have been utilised by seafarers with primary school education (relative probability ratio [RPR] $2.40 ; 1.10,5.22)$ compared with lower than primary education and by seafarers whose average duration of fishing trip was no more than 10 days. There was some indication that being a mechanic or cook was associated with a higher relative probability of using a private rather than public healthcare facility compared with being a crew supervisor.

By contrast, compared with the baseline outcome of using a public healthcare facility, seeking healthcare from drug stores was relatively more likely among non-drinkers (RPR 2.50; 1.19, 5.15), and those with low income ( $\leq 8000$ Baht/month) (RPR 6.13; 1.32, 28.4), and basic marine workers with the job of sorting, packing and storing the catch compared with workers responsible for steering and/or navigation (Table 4).

\section{QUALITATIVE INFORMATION}

The most common health-related experiences that occurred at sea were reported to be abdominal discomfort, loose motion, sea-sickness, body aches, alcohol withdrawal 
Table 3. Illness (in the previous year) of Myanmar migrant seafarers in Pattani district, Thailand $(n=385)$

\begin{tabular}{|c|c|c|c|c|}
\hline Exposure & Adjustment set & Exposure variable level & OR (95\% Cl) & $\begin{array}{l}\text { P value } \\
\text { (LR test) }\end{array}$ \\
\hline Type of job on boat & $\begin{array}{l}\text { Heath education, } \\
\text { education level }\end{array}$ & $\begin{array}{l}\text { Supervise crew } \\
\text { Steer vessel and navigation } \\
\text { Mechanic and cook } \\
\text { Sort, pack and store catch } \\
\text { Guide nets, traps and line }\end{array}$ & $\begin{array}{l}7.67(1.01-57.9)^{\mathrm{a}} \\
1.09(0.52-2.28)^{\mathrm{ab}} \\
0.57(0.18-1.74)^{\mathrm{b}} \\
1^{\mathrm{b}} \\
0.52(0.20-1.36)^{\mathrm{b}}\end{array}$ & 0.031 \\
\hline Age [years] & - & $\begin{array}{l}\leq 20 \\
>20\end{array}$ & $\begin{array}{l}1 \\
2.05(1.05-4.01)\end{array}$ & 0.043 \\
\hline Drinking & Health education & $\begin{array}{l}\text { Ex and current } \\
\text { Never }\end{array}$ & $\begin{array}{l}3.17(1.84-5.46) \\
1\end{array}$ & $<0.001$ \\
\hline Ethnicity & - & $\begin{array}{l}\text { Bamar } \\
\text { Rakhine } \\
\text { Dawei and others }\end{array}$ & $\begin{array}{l}1.56(0.80-3.05)^{a b} \\
1^{a} \\
4.46(1.34-14.9)^{b}\end{array}$ & 0.009 \\
\hline $\begin{array}{l}\text { Exposure to hazardous } \\
\text { marine life }\end{array}$ & $\begin{array}{l}\text { Job type, fishing trip } \\
\text { duration }\end{array}$ & $\begin{array}{l}\text { No } \\
\text { Yes }\end{array}$ & $\begin{array}{l}1 \\
2.36(1.24-4.48)\end{array}$ & 0.006 \\
\hline $\begin{array}{l}\text { Length of stay in Thailand } \\
\text { [years] }\end{array}$ & - & $\begin{array}{l}<5 \\
\geq 5\end{array}$ & $\begin{array}{l}1 \\
4.10(1.97-8.54)\end{array}$ & $<0.001$ \\
\hline $\begin{array}{l}\text { Working duration in current } \\
\text { job [years] }\end{array}$ & - & $\begin{array}{l}<5 \\
\geq 5\end{array}$ & $\begin{array}{l}1 \\
4.21(1.86-9.50)\end{array}$ & $<0.001$ \\
\hline
\end{tabular}

Table 4. Choice of healthcare facility among Myanmar migrant seafarers who sought healthcare for illness within the previous year in Pattani district, Thailand $(\mathrm{n}=236)$

\begin{tabular}{|c|c|c|c|c|c|c|c|}
\hline \multirow[t]{2}{*}{ Exposure } & \multirow{2}{*}{$\begin{array}{l}\text { Adjustment } \\
\text { set }\end{array}$} & \multirow[t]{2}{*}{ Exposure variable level } & \multicolumn{4}{|c|}{ Relative probability ratio } & \multirow{2}{*}{$\begin{array}{l}\text { P value } \\
\text { (LR test) }\end{array}$} \\
\hline & & & $\begin{array}{l}\text { Private care vs. } \\
\text { public hospital }\end{array}$ & $\begin{array}{l}\text { P value } \\
\text { (Wald } \\
\text { test) }\end{array}$ & $\begin{array}{l}\text { Drug store } \\
\text { vs. public } \\
\text { hospital }\end{array}$ & $\begin{array}{l}\text { P value } \\
\text { (Wald } \\
\text { test) }\end{array}$ & \\
\hline Drinking & $\begin{array}{l}\text { Health } \\
\text { education }\end{array}$ & $\begin{array}{l}\text { No } \\
\text { Ex-or current drinker }\end{array}$ & $\begin{array}{l}0.82(0.32,2.12) \\
1\end{array}$ & 0.685 & $\begin{array}{l}2.50(1.19,5.15) \\
1\end{array}$ & 0.015 & 0.022 \\
\hline $\begin{array}{l}\text { Level of } \\
\text { education }\end{array}$ & $\begin{array}{l}\text { Age, } \\
\text { ethnicity }\end{array}$ & $\begin{array}{l}<\text { Primary school } \\
\text { Primary school and above }\end{array}$ & $\begin{array}{l}1 \\
2.40(1.10,5.22)\end{array}$ & 0.022 & $\begin{array}{l}1 \\
0.92(0.49,1.71)\end{array}$ & 0.784 & 0.042 \\
\hline $\begin{array}{l}\text { Income } \\
\text { (Baht/mo.) }\end{array}$ & $\begin{array}{l}\text { Age, working du- } \\
\text { ration, job type }\end{array}$ & $\begin{array}{l}>8000 \\
<8000\end{array}$ & $\begin{array}{l}1 \\
2.02(0.92,4.47)\end{array}$ & 0.081 & $\begin{array}{l}1 \\
6.13(1.32,28.4)\end{array}$ & 0.020 & 0.049 \\
\hline $\begin{array}{l}\text { Type of } \\
\text { job on boat }\end{array}$ & $\begin{array}{l}\text { Ethnicity, educa- } \\
\text { tion level }\end{array}$ & $\begin{array}{l}\text { Supervise crew } \\
\text { Steer vessel and navigation } \\
\text { Mechanic and cook } \\
\text { Sort, pack and store catch } \\
\text { Guide nets, traps and line }\end{array}$ & $\begin{array}{l}0.33(0.10,1.11)^{\mathrm{a}} \\
0.51(0.20,1.31)^{\mathrm{ab}} \\
2.80(0.50,15.7)^{\mathrm{b}} \\
1^{\mathrm{ab}} \\
0.48(0.04,5.12)^{\mathrm{ab}}\end{array}$ & 0.181 & $\begin{array}{l}0.42(0.15,1.15)^{\mathrm{ab}} \\
0.20(0.06,0.65)^{\mathrm{a}} \\
1.43(0.27,7.54)^{\mathrm{ab}} \\
1^{\mathrm{b}} \\
1.40(0.26,7.48)^{\mathrm{ab}}\end{array}$ & 0.042 & 0.044 \\
\hline $\begin{array}{l}\text { Average } \\
\text { fishing trip } \\
\text { days }\end{array}$ & - & $\begin{array}{l}\leq 10 \\
11-15 \\
>16\end{array}$ & $\begin{array}{l}1^{c} \\
0.18(0.06,0.55)^{a} \\
0.41(0.18,0.93)^{b}\end{array}$ & 0.003 & $\begin{array}{l}1 \\
0.97(0.46,2.03) \\
0.99(0.48,2.02)\end{array}$ & 0.997 & 0.005 \\
\hline
\end{tabular}

symptoms, illicit drug reaction, accidental injuries and minor cutaneous lesions. The crew supervisor took care of health for crew members when minor illness occurred at sea with the help of emergency kit medicines. If the disease condition became worse, other options to obtain health treatment were considered such as sending the patient back to shore via fishing boat or other carrier boat. A one-time explosion and fire at sea was reported and in that situation, the injured seafarers received treatment and medical aids from a nearby offshore oil and gas production rig.

Regarding health-related experience on land, as Thai employers usually kept the employee's health insurance 
card, seafarers quite commonly went to a private clinic or requested treatment at a home visit by nurse or paramedic rather than visit a public hospital. The language barrier, transportation cost and caretaker charges (fees for accompanying translator) were mentioned as additional reasons for seeking healthcare privately rather that visiting a public healthcare facility. Sometimes, seafarers avoided seeking professional treatment and instead self-medicated with medicine bought at a nearby drug store. Some generous and dutiful employers took care of their employee and shared high health cost. Seafarers wanted employers to eliminate unfair wage deductions and ensure timely payment of wages in full.

While staying ashore, seafarers were not allowed to go outside the camps or travel across the province as they did not have their identification documentation in their hands. A few seafarers pointed out that a seafarer's life was harder in Thailand than in their mother country as they earned less than expected and because of their being in debt for recruitment fees. However, one long-service fisherman said that current conditions were considerably better than in the early years of his seafaring occupation: todays' seafarers, he said, had full documentation for fishing, work permits and health insurance benefits and their boss also took full responsibility for migrant seafarer's health, families and social wellbeing.

\section{DISCUSSION}

This study of Myanmar migrant seafarers aged 17-53 years from one fishing community in a southern Thailand coastal port recorded their working conditions at sea and their healthcare seeking preferences. A small qualitative interview highlighted the relationship of migrant seafarers with their employers and the suggested labour abuses in the Thailand fishing and seafood industry. Healthcare utilisation by migrant seafarers at public hospitals was quite low.

Overall, less than $40 \%$ of the migrant seafarers went to a public hospital when they were sick, with most crew members other than supervisors and navigators choosing to visit private facilities or simply obtain medication from drug stores. This may be owing to the fact that the seafarers' health insurance cards were mostly kept by their boss. Nevertheless, almost all seafarers had undergone health screening services as this was mandated for being provided with a work permit and health insurance. Although law prohibits withholding of identification documents [2], Thai employers of almost all migrant employees' kept the seafarers' identity cards. In this study, only $2.3 \%$ of migrant workers could keep their cards themselves or with a friend or relative.

Over $70 \%$ of seafarers in this study were or had been smokers and/or alcohol consumers. A few of them also used illicit drugs. Thus, not only were the seafarers working in a physically hazardous job but the use of alcohol and illicit drugs would likely add to the risk of their having risky behaviours for sexually transmitted diseases (STI) and other communicable diseases. A cross-sectional study conducted among Myanmar fishermen in Ranong, Thailand described their risky sexual behaviours such as penile oil injection, penile implantation and poor condom use [14]. According to the nationwide hospital database for 2011, tuberculosis, malaria and STI were prevalent in male migrant workers in Thailand [15]. A study done in a fisherman community stated that self-treatment of STI was significantly more frequent among Myanmar migrant fishermen than Khmer or Thai [16]. Though the current study did not collect data on the types of illness experienced, the results showed that those who drank alcohol were more likely to have been ill in the previous year.

Seafarers who had received at least primary level education more commonly chose to seek healthcare at private clinics, while those who no more than 8000 Baht per month were more likely to seek medication from a drug store. Preferring to seek private treatment or adopt self-medication may be because seafarers would need to retrieve their identity and health insurance documents from their boss to visit a public hospital and may feel reluctant to discuss with their crew supervisor or boss about their illness. Alternatively, they may decide their illness is only minor and ignore it. A fishermen study done in Thailand reported higher proportion of self-medication among Myanmar and Khmer fishermen than among Thai fishermen [16]. To encourage greater utilisation of migrant health insurance at public health facilities, migrant seafarers should be allowed to keep their identity and health insurance documents themselves.

Seafarers who went to sea for on average less than 10 days per trip were more likely to get treatment at private clinics or have home visit treatment. Except for major injury and illness, they wanted to avoid long queues and subsequent follow up visits at hospital, disregarding the need for proper investigation and treatment. Without long hospital stay, seafarers assumed that they were not absent from their duty station and could maintain their income intact. Moreover, half of the fishermen in the study were unmarried, and being far from their families and relatives could rely for support only on their coworkers when they were ill.

The qualitative information revealed that the migrant seafarers were generally satisfied with the available treatment options at sea and on land. However, seafarers wished to keep their health insurance cards so that they could utilize their rights to healthcare access at public hospitals. Seizure of workers' identification documents by employers, delayed payments and a lack of labour protection are considered 
to be employment abuses [17]. Seafarers also wanted to improve their social security and wellbeing and ensure a healthy working environment while omitting some abusive working condition. The pattern of healthcare-seeking preferences of migrants was similar from one camp to another in this study, although the perceived attitude of the boss at different camps resulted in some differences in healthcare access and benefits.

\section{LIMITATIONS OF THE STUDY}

Limitations of this study are the cross-sectional design which limits causal inference. Also, the highly mobile nature of migrant fishermen meant that the seafarers included in the study were sampled from those who happened to be ashore at the time of the data collection. The self-reporting of illness in the previous year may also have been subject to bias; in particular, it is not certain that the illnesses reported actually occurred within the space of the previous 12 months. Indeed, the strong association between reported illness and duration of residence in Thailand suggests that some of the illnesses reported may actually have occurred earlier. Generalisability of findings to other migrant seafarer communities should be considered with caution as the study was confined to just one location in southern Thailand.

Nevertheless, the study has an important strength. The fact that seafarers and the interviewer were of the same nationality, if not all of the same ethnicity, suggests that migrant-interviewees felt safe to respond well and truthfully to the questions. The advocate skill of key informants also supported the seafarers' willingness to respond.

\section{CONCLUSIONS}

In conclusion, despite the high insurance coverage for registered migrants and expanding coverage for undocumented migrants, Thailand still faces unresolved operational challenges. Given the pattern of healthcare-seeking preferences of migrant seamen, more migrant-friendly health services are still needed. Such health services should be supported not only by the government policy but also by employers' participation. Effective information, education, and communication materials written in mother language of migrants should be provided to promote migrant workers' knowledge on health issues and enhance sensible decision-making regarding their healthcare. Future lawful enforcement needs to be strengthened to deliver greater adherence to labour and social protection in this migrant society.

\section{ACKNOWLEDGEMENTS}

The authors wish to acknowledge Professor Virasakdi Chongsuvivatwong for his helpful advice in this study and express their gratitude to the key informants for their active support and information and their heartfelt thanks to all the migrant seafarers for their patient participation in the study. The Graduate School, Prince of Songkla University, is gratefully acknowledged for financial support of the first author.

The study is part of a thesis by PPK for fulfilment of the Master of Science in Epidemiology Course at the Prince of Songkla University. This study was financially supported by The Graduate School, Prince of Songkla University through Thailand International Cooperation Agency (TICA).

\section{CONFLICT OF INTEREST}

The authors declare that they have no competing interests.

\section{REFERENCES}

1. World Migration Report 2018, International Organization for Migration. 2017. https://www.iom.int/wmr/world-migration-report-2018 (Accessed 14 May 2019).

2. Thailand Migration Report 2019. International Organization for Migration Thailand. 2019. https://thailand.iom.int/thailand-migration-report-2019-0 (Accessed 14 May 2019).

3. World Health Organization. Implementing health insurance for migrants, Thailand. World Health Organization. 2017. Available: http:// www.who.int/bulletin/volumes/95/2/16-179606/en/. Accessed 14 May 2019. Bull World Health Organ. 2017; 95(2): 146-151, doi: 10.2471/BLT.16.179606.

4. Lwin SW, Geater AF. Ethnic Groups and Father's Job Influencing Nutritional Status of Children (0-30 months) from Myanmar Migrant Community in Southern Thailand. J Racial Ethn Health Disparities. 2019; 6(5): 944-952, doi: 10.1007/s40615-019-00595-8, indexed in Pubmed: 31065998.

5. Parasuraman G, Sivakumar K, Shilpa BP, et al. What ails the fishermen community in Ennore Creek: a socio-demographic analysis. Indian J Sci Technol. 2016; 9(25), doi: 10.17485/ijst/2016/v9i25/94834.

6. Malakauskiene R, Health related quality of life among seamen-focus on Lithuanian seamen. Master of Science thesis, Blekinge Institute of Technology, School of Health Science; 2006.

7. Rengamani J, Murugan MS. A study on the factors influencing the seafarers' stress. AMET Int J Manag. 2012; 4: 44-51.

8. McMichael C, Healy J. Health equity and migrants in the Greater Mekong Subregion. Glob Health Action. 2017; 10(1): 1271594, doi: 10.1080/16549716.2017.1271594, indexed in Pubmed: 28452652.

9. Peng Y, Chang W, Zhou H, et al. Factors associated with health-seeking behavior among migrant workers in Beijing, China. BMC Health Serv Res. 2010; 10: 69, doi: 10.1186/1472-6963-10-69, indexed in Pubmed: 20298613.

10. Tangcharoensathien V, Thwin AA, Patcharanarumol W. Implementing health insurance for migrants, Thailand. Bull World Health Organ. 2017; 95(2): 46-51, doi: 10.2471/BLT.17.000217.

11. Onarheim KH, Melberg A, Meier BM, et al. Towards universal health coverage: including undocumented migrants. BMJ Glob Health. 2018; 3(5): e001031, doi: 10.1136/bmjgh-2018-001031, indexed in Pubmed: 30364297.

12. Aung T, Pongpanich S, Robson MG. Health-seeking behaviors among Myanmar migrant workers in Ranong Province, Thailand. J Health Res. 2009; 23: 5-9.

13. Lawrie T, Matheson C, Murphy E, et al. Medical emergencies at sea and injuries among Scottish fishermen. Occup Med (Lond). 
2003; 53(3): 159-164, doi: 10.1093/occmed/kqg054, indexed in Pubmed: 12724549.

14. Ohnmar, Geater AF, Winn T, Chongsuvivatwong V. Penile oil injection, penile implantation and condom use among Myanmar migrant fishermen in Ranong, Thailand. Sex Health. 2009; 6(3): 217-221, doi: 10.1071/SH08077, indexed in Pubmed: 19653959.

15. Rakprasit J, Nakamura K, Seino K, et al. Healthcare use for communicable diseases among migrant workers in comparison with Thai workers. Ind Health. 2017; 55(1): 67-75, doi: 10.2486/ indhealth.2016-0107, indexed in Pubmed: 27568679.
16. Entz A, Prachuabmoh V, van Griensven F, et al. STD history, self treatment, and healthcare behaviours among fishermen in the Gulf of Thailand and the Andaman Sea. Sex Transm Infect. 2001; 77(6): 436-440, doi: 10.1136/sti.77.6.436, indexed in Pubmed: 11714943.

17. Suphanchaimat R, Pudpong N, Tangcharoensathien V. Extreme exploitation in Southeast Asia waters: Challenges in progressing towards universal health coverage for migrant workers. PLoS Med. 2017; 14(11): e1002441, doi: 10.1371/journal.pmed.1002441, indexed in Pubmed: 29166397. 